\title{
Petanda Imunofenotip CD10 Sendiri Atau Bersama CD3 Atau CD13/ CD33 sebagai Faktor Prognosis Luaran Terapi Fase Induksi Leukemia Limfoblastik Akut Anak
}

Eggi Arguni, Sasmito Nugroho, Sri Mulatsih, Sutaryo

Departemen Ilmu Kesehatan Anak Fakultas Kedokteran Universitas Gadjah Mada/RSUP Dr. Sardjito, Yogyakarta

Latar belakang. Kegagalan terapi masih menjadi penyumbang terbesar bagi mortalitas anak dengan leukemia limfoblastik akut (LLA). Ekspresi CD10 menentukan diferensiasi sebagian besar leukemia sel B. Petanda imunofenotip untuk LLA sel T, yaitu CD3, dan myeloid antigen, yaitu CD13/CD33, dengan jumlah kecil juga terekspresi pada B-ALL.

Tujuan. Mengetahui pengaruh ekspresi CD10 sendiri atau bersama dengan CD3 atau CD13/CD33 terhadap luaran terapi fase induksi LLA anak.

Metode. Desain penelitian menggunakan nested case-control. Sampel penelitian merupakan pasien LLA anak yang baru terdiagnosis di INSKA RSUP Dr Sardjito Yogyakart Januari 2006-Desember 2009, dilengkapi pemeriksaan imunofenotip saat penegakan diagnosis. Analisis bivariat dan multivariat digunakan untuk menentukan faktor prognosis independen terhadap luaran terapi.

Hasil. Seratus enam puluh tujuh pasien diikutsertakan dalam penelitian ini. Faktor usia dan ekspresi CD10 merupakan faktor prognosis independen yang menentukan luaran terapi fase induksi. Kelompok usia $<1$ tahun dan $\geq 10$ tahun akan mengalami gagal remisi (OR 3,1; IK95\%:1,271-7,625; p=0,013), dan LLA anak dengan CD10 negatif akan mengalami gagal remisi 2,7 kali lebih tinggi dibanding CD10 positif (IK95\%:1,171-6,232; p=0,020).

Kesimpulan. CD10 negatif merupakan faktor prognosis independen terhadap kejadian gagal remisi. Ekspresi imunofenotip CD10 bersama CD3 dan CD13/CD33, bukan merupakan faktor prognosis bagi luaran terapi fase induksi. Sari Pediatri 2018;19(5):260-6

Kata kunci: CD10, CD3, CD13/CD33, acute lymphoblastic leukemia, anak

\section{CD10 or Together with CD3 OR CD13/CD33 aS Prognostic Factors For Induction Phase Outcome In Childhood Acute Lymphoblastic Leukemia}

Eggi Arguni, Sasmito Nugroho, Sri Mulatsih, Sutaryo

Background. Therapeutic failure remains the major cause of high morbidity and mortality in childhood acute lymphoblastic leukemia (ALL). The heterogeneity of lymphocyte antigens and receptors differentiation should be thought as one which responsible for this mechanism of failure. The lymphocyte surface expression of CD10 marks the differentiation of lymphoblastic leukemia. The lack of its expression may indicate a special group of ALL. T-cell acute lymphoblastic leukemia, CD3, and myeloid association antigen, CD13/CD33, in small population are expressed in B cell ALL as well.

Objective. The aim of this study was to assess the independent significance of CD10 alone or together with CD3 and CD13/CD33 expression to the induction phase outcome of childhood ALL.

Methods. By using the nested case control method, we collect and analyze the sample of newly diagnosed childhood ALL in Pediatric Department Dr Sardjito Hospital Yogyakarta enrolled between January 1, 2006 and December 31, 2009 for whom a complete immunophenotyping profile examination. Bivariate and multivariate analyses were used to find the independent prognostic factors of treatment outcome

Result. One hundred and sixty seven patients were enrolled. Age and CD10 were independent prognostic factors for remission failure after induction phase. Age group of $<1$ year old and $\geq 10$ year old will have remission failure (OR 3.1, 95\%CI :1.271-7.625, $\mathrm{p}=0.013)$. CD10 negative patient have 2.7 times higher possibility of failure in induction phase than the ones who have CD10 expression (95\%CI 1:171-6.232, $\mathrm{p}=0.020)$.

Conclusion. CD10 expression is the independent prognostic factors for remission failure. Sari Pediatri 2018;19(5):260-6

Keywords: CD10, CD3, CD13/CD33, acute lymphoblastic leukemia, childhood

Alamat korespondensi: Dr. Eggi Arguni, MSc., PhD SpA. Departemen Ilmu Kesehatan Anak Fakultas Kedokteran UGM Jl. Farmako, Sekip, Yogyakarta 55281. Email: eggiarguni@ugm.ac.id 
Eggi Arguni dkk: Petanda imunofenotip CD10 sendiri atau bersama CD3 atau CD13/CD33 sebagai faktor prognosis luaran terapi fase induksi LLA

L

eukemia limfoblastik akut (LLA) merupakan keganasan hematologi yang paling sering dijumpai pada anak. ${ }^{1} \mathrm{Di}$ Eropa sekitar 5000 anak terdiagnosis LLA setiap tahunnya. ${ }^{2,3}$ Di Yogyakarta yang berpenduduk 4 juta, sekitar 30-40 anak akan terdiagnosis LLA setiap tahunnya. ${ }^{4}$ Keadaan bebas gejala selama 5 tahun (the five-year event free survival rate) mencapai 80\% pada kasus LLA anak. ${ }^{56}$ Perbaikan protokol terapi dan perawatan suportif menghasilkan remisi komplit $98 \%{ }^{7} \mathrm{Di}$ balik keberhasilan tersebut, mortalitas yang tinggi akibat penyakit utama dan morbiditas yang tinggi akibat kemoterapi yang diterima masih perlu dipikirkan. Pasien LLA anak di RSUP Dr. Sardjito yang mengalami remisi komplit $69 \%$, meninggal $12 \%$, tidak remisi $5 \%$ dan drop out $13 \%$. Leukemia limfoblastik akut dengan risiko standar mengalami remisi komplit $75 \%$ dan dengan risiko tinggi $60 \%$. Angka kematian dengan risiko standar pada fase induksi $8,8 \%$ dan risiko tinggi $17,7 .{ }^{8}$

Petanda imunofenotip (immunophenotypic markers) telah digunakan dalam mendiagnosis dan mengklasifikasi LLA pada anak dan telah banyak diteliti memiliki peran dalam menentukan prognosis LLA anak. CD10 merupakan petanda awal yang diekspresikan oleh sel-sel leukemia dalam lymphoblastic lineage. Peran CD10 dalam leukemogenesis sebenarnya belumlah jelas, tetapi ekspresinya diperlukan untuk regulasi faktor pertumbuhan sehingga berperan dalam maturasi sel limfosit. ${ }^{9}$ Ekspresi CD10 menentukan diferensiasi sebagian besar leukemia sel B. Tidak adanya ekspresi CD10 (CD10 negatif) menandakan sub tipe LLA yang spesial. Petanda imunofenotip untuk LLA sel T (T-cell acute lymphoblastic leukemia), yaitu CD3, dan antigen myeloid, yaitu CD13 dan CD33, dengan jumlah kecil juga terekspresi pada LLA sel B (B-ALL, B cellacute lymphoblastic leukemia). LLA sel T (T-ALL, $T$ cell-acute lymphoblastic lenkemia) dan leukemia dengan myeloid antigen positif memiliki prognosis yang lebih buruk dibandingkan LLA sel B. Ekspresi CD10 bersamaan dengan ekspresi CD3 dan CD13/ CD33 tentunya juga akan mempengaruhi prognosis LLA anak.

Tujuan penelitian ini adalah untuk mengetahui pengaruh ekspresi CD10 sendiri atau bersama dengan CD3 atau CD13/CD33 terhadap luaran terapi fase induksi LLA anak.

\section{Metode}

Penelitian ini menggunakan data registri pasien LLA di Divisi Hemato Onkologi Departemen Ilmu Kesehatan Anak/Instalasi Kesehatan Anak RSUP Dr Sardjito Yogyakarta periode Januari 2006 - 31 Desember 2009, yang menjalani pemeriksaan imunofenotiping pada saat penegakan diagnosis. Rentang usia pasien 1-14 tahun. Diagnosis LLA berdasarkan kriteria morfologis dan sitokimia (FAB). Protokol LLA yang digunakan adalah Protokol Indonesia 2006. Dalam protokol ini fase induksi dilakukan selama 4-6 minggu menggunakan Kortikosteroid (Prednisone/ Dexamethasone), Vincristine, L-Asparaginase, dan Anthracycline. Luaran fase induksi berupa remisi dan gagal remisi dilihat dari data di akhir fase induksi selesai. Disebut remisi apabila dijumpai sel blast dalam sumsum tulang $<5 \%$ per 200 sel berinti dan tidak ditemukan sel blast di darah tepi, cairan serebrospinal serta tidak ditemukan infiltrasi di tempat lain yang diperiksa di akhir fase induksi. Kriteria eksklusi adalah pasien yang menolak kemoterapi, dropped out atau meninggal sebelum menjalani terapi induksi.

Ekspresi CD10, CD3 dan CD13/CD33 bersama marker yang lain diketahui menggunakan flow cytometry (Profile II, Coulter or Facscan, Becton Dickinson) yang di lakukan di Laboratorium Biologi Molekuler dan Patologi Klinik Fakultas Kedokteran Universitas Gadjah Mada.

Analisis univariat dengan $\mathrm{x}^{2}$ dilakukan untuk mengetahui perbedaan pengaruh faktor prognosis terhadap luaran terapi. Untuk mengetahui pengaruh faktor prognosis terhadap luaran digunakan analisis bivariat dengan interval kepercayaan 95\%. Analisis stepwise multivariat dengan regresi logistik digunakan untuk mengetahui faktor prognosis yang bermakna secara independen terhadap luaran terapi.

\section{Hasil}

Data pasien di Instalasi Kesehatan Anak (INSKA) RSUP Dr Sardjito Januari 2006 sampai Desember 2009 didapat 241 subjek LLA baru. Jumlah pasien yang diikutsertakan dalam penelitian ini dan yang melanjutkan terapi 167 pasien. Gambaran karakteristik pasien, yaitu jenis kelamin, usia, angka leukosit awal, tipe leukemia menurut kriteria FAB, kelompok risiko, status imunofenotip berdasarkan ekspresi CD10, CD3, 
Eggi Arguni dkk: Petanda imunofenotip CD10 sendiri atau bersama CD3 atau CD13/CD33 sebagai faktor prognosis luaran terapi fase induksi LLA

dan CD13/CD33 tertera pada Tabel 1.

Dari 167 pasien yang menjalani terapi fase induksi, 121 remisi dan 46 gagal remisi karena mengalami tidak remisi $(3,0 \%)$, dropped out $(7,8 \%)$ atau meninggal $(16,8 \%)$. Sebagian besar pasien remisi adalah dengan CD10 positif $(71,1 \%)$, CD3 negatif $(81,8 \%)$, dan
CD13/CD33 negatif (82,6\%) (Tabel 2).

Luaran fase induksi ini hanya berbeda bermakna berdasarkan ekspresi CD10 ( $\mathrm{p}=0,004)$, tidak berdasarkan ekspresi imunofenotip yang lain (CD3 $\mathrm{p}=0,818$ dan CD13/CD33 p=0,930). Untuk luaran fase induksi berdasarkan koekspresi CD10 dengan

Tabel 1. Karakteristik klinis 167 pasien yang menjalani terapi induksi

\begin{tabular}{|c|c|c|c|c|c|c|c|c|c|c|}
\hline \multirow[b]{2}{*}{ Karakteristik klinis } & \multirow[b]{2}{*}{$\begin{array}{l}\mathrm{N} \\
(\%)\end{array}$} & \multicolumn{2}{|c|}{$\mathrm{CD} 10$} & \multirow[b]{2}{*}{$\mathrm{p}$} & \multicolumn{2}{|c|}{$\mathrm{CD} 3$} & \multirow[b]{2}{*}{ p } & \multicolumn{2}{|c|}{$\mathrm{CD} 13 / \mathrm{CD} 33$} & \multirow[b]{2}{*}{$\mathrm{p}$} \\
\hline & & $\begin{array}{l}\text { Positif } \\
(\mathrm{n}=108)\end{array}$ & $\begin{array}{l}\text { Negatif } \\
(\mathrm{n}=59)\end{array}$ & & $\begin{array}{l}\text { Positif } \\
(\mathrm{n}=29)\end{array}$ & $\begin{array}{c}\text { Negatif } \\
(\mathrm{n}=138)\end{array}$ & & $\begin{array}{l}\text { Positif } \\
(\mathrm{n}=31)\end{array}$ & $\begin{array}{l}\text { Negatif } \\
(\mathrm{n}=136)\end{array}$ & \\
\hline $\begin{array}{l}\text { Jenis kelamin } \\
\text { Laki-laki } \\
\text { Perempuan }\end{array}$ & $\begin{array}{l}96(57,5) \\
71(42,5)\end{array}$ & $\begin{array}{l}59(61,5) \\
49(69,0)\end{array}$ & $\begin{array}{l}37(38,5) \\
22(31,0)\end{array}$ & 0,313 & $\begin{array}{l}19(19,8) \\
10(14,1)\end{array}$ & $\begin{array}{l}77(80,2) \\
61(85,9)\end{array}$ & 0,336 & $\begin{array}{l}21(21,9) \\
10(14,1)\end{array}$ & $\begin{array}{l}75(78,1) \\
61(85,9)\end{array}$ & 0,201 \\
\hline $\begin{array}{l}\text { Usia } \\
<1 \text { th, } \geq 10 \text { th } \\
1-<10 \text { th }\end{array}$ & $\begin{array}{c}35(21,0) \\
132(79,0)\end{array}$ & $\begin{array}{l}21(60,0) \\
87(63,9)\end{array}$ & $\begin{array}{l}14(40,0) \\
45(34,1)\end{array}$ & 0,516 & $\begin{array}{c}7(20,0) \\
22(16,7)\end{array}$ & $\begin{array}{c}28(80,0) \\
110(83,3)\end{array}$ & 0,643 & $\begin{array}{c}6(17,1) \\
25(18,9)\end{array}$ & $\begin{array}{c}29(82,9) \\
107(81,1)\end{array}$ & 0,808 \\
\hline $\begin{array}{l}\text { Angka lekosit } \\
250.000 / \mathrm{ml} \\
<50.000 / \mathrm{ml}\end{array}$ & $\begin{array}{c}56(33,5) \\
111(66,5)\end{array}$ & $\begin{array}{l}28(50,0) \\
80(72,1)\end{array}$ & $\begin{array}{l}28(50,0) \\
31(27,9)\end{array}$ & $0,005^{*}$ & $\begin{array}{l}12(21,4) \\
17(15,3)\end{array}$ & $\begin{array}{l}44(78,6) \\
94(84,7)\end{array}$ & 0,325 & $\begin{array}{c}9(16,1) \\
22(19,8)\end{array}$ & $\begin{array}{l}47(83,9) \\
89(80,2)\end{array}$ & 0,556 \\
\hline $\begin{array}{l}\text { Tipe LLA } \\
\text { L1 } \\
\text { L2 } \\
\text { L1/L2 } \\
\quad \text { Undiff }\end{array}$ & $\begin{array}{c}129(77,2) \\
36(21,6) \\
1(0,01) \\
1(0,01)\end{array}$ & $\begin{array}{c}84(65,1) \\
23(63,9) \\
0(0,0) \\
1(100,0)\end{array}$ & $\begin{array}{c}45(34,9) \\
13(36,1) \\
1(100,0) \\
0(0,0)\end{array}$ & 0,494 & $\begin{array}{l}21(16,3) \\
6(16,7) \\
1(100,0) \\
1(100,0)\end{array}$ & $\begin{array}{c}108(83,7) \\
30(83,3) \\
0(0,0) \\
0(0,0)\end{array}$ & $0,022^{*}$ & $\begin{array}{c}24(18,6) \\
7(19,4) \\
0(0,0) \\
0(0,0)\end{array}$ & $\begin{array}{l}105(81,4) \\
29(80,6) \\
1(100,0) \\
1(100,0)\end{array}$ & 0,924 \\
\hline $\begin{array}{l}\text { Kelompok risiko } \\
\text { Risiko standar } \\
\text { Risiko tinggi }\end{array}$ & $\begin{array}{l}72(43,1) \\
95(56,9)\end{array}$ & $\begin{array}{l}56(77,8) \\
52(54,7)\end{array}$ & $\begin{array}{l}16(22,2) \\
43(47,3)\end{array}$ & $0,002^{*}$ & $\begin{array}{c}8(11,1) \\
21(22,1)\end{array}$ & $\begin{array}{l}64(88,9) \\
74(77,9)\end{array}$ & 0,063 & $\begin{array}{l}16(22,2) \\
15(15,8)\end{array}$ & $\begin{array}{l}56(77,8) \\
80(84,2)\end{array}$ & 0,290 \\
\hline $\begin{array}{l}\text { Imunofenotip } \\
\text { B-ALL } \\
\text { T-ALL }\end{array}$ & $\begin{array}{c}136(81,4) \\
31(18,6)\end{array}$ & $\begin{array}{c}100(73,5) \\
8(25,8)\end{array}$ & $\begin{array}{l}36(26,5) \\
23(74,2)\end{array}$ & $0,000^{*}$ & $\begin{array}{l}17(12,5) \\
12(38,7)\end{array}$ & $\begin{array}{c}119(87,5) \\
19(61,3)\end{array}$ & $0,001^{*}$ & $\begin{array}{c}25(18,4) \\
6(19,4)\end{array}$ & $\begin{array}{c}111(81,6) \\
25(80,6)\end{array}$ & 0,900 \\
\hline
\end{tabular}

${ }^{*} \mathrm{P}<0.05$ (analisis statistik menunjukkan signifikansi)

Tabel 2. Luaran fase induksi pasien yang menjalani terapi berdasarkan imunofenotip CD10, CD3 dan CD13/CD33

\begin{tabular}{|c|c|c|c|c|c|c|c|c|c|c|c|c|c|c|c|c|c|}
\hline \multirow[t]{2}{*}{ Luaran terapi } & \multirow{2}{*}{$\begin{array}{l}\mathrm{N} \\
(\%)\end{array}$} & \multicolumn{2}{|c|}{ CD10 } & \multirow[t]{2}{*}{$p$} & \multicolumn{2}{|c|}{$\mathrm{CD} 3$} & \multirow[t]{2}{*}{$\mathrm{p}$} & \multicolumn{2}{|c|}{$\mathrm{CD} 13 / \mathrm{CD} 33$} & \multirow[t]{2}{*}{$\mathrm{p}$} & \multirow{2}{*}{$\begin{array}{l}\mathrm{N} \\
(\%)\end{array}$} & \multicolumn{2}{|c|}{$\mathrm{CD} 10(+)$} & \multirow[t]{2}{*}{$p$} & \multicolumn{2}{|c|}{ CD10(+) } & \multirow[t]{2}{*}{$\mathrm{p}$} \\
\hline & & Positif & Negatif & & Positif & Negatif & & Positif & Negatif & & & $\begin{array}{c}\text { CD3 } \\
(+) \\
(\mathrm{n}=17)\end{array}$ & $\begin{array}{c}\text { CD3 } \\
(-) \\
(\mathrm{n}=91)\end{array}$ & & $\begin{array}{c}\mathrm{CD} 13 / \\
\mathrm{CD} 33 \\
(+) \\
(\mathrm{n}=20)\end{array}$ & $\begin{array}{c}\mathrm{CD} 13 / \\
\mathrm{CD} 33 \\
(-) \\
(\mathrm{n}=88)\end{array}$ & \\
\hline Jumlah pasien & $\begin{array}{c}167 \\
(100,0)\end{array}$ & $\begin{array}{c}108 \\
(64,7)\end{array}$ & $\begin{array}{c}59 \\
(35,3)\end{array}$ & $0,004^{*}$ & $\begin{array}{c}29 \\
(17,4)\end{array}$ & $\begin{array}{c}138 \\
(82,6)\end{array}$ & 0,818 & $\begin{array}{c}31 \\
(18,6)\end{array}$ & $\begin{array}{c}136 \\
(81,4)\end{array}$ & 0,930 & $\begin{array}{c}108 \\
(100,0)\end{array}$ & $\begin{array}{c}17 \\
(15,7)\end{array}$ & $\begin{array}{c}91 \\
(84,3)\end{array}$ & $0,044^{*}$ & $\begin{array}{c}20 \\
(18,5)\end{array}$ & $\begin{array}{c}88 \\
(81,5)\end{array}$ & 0,078 \\
\hline Remisi & $\begin{array}{c}121 \\
(72,4)\end{array}$ & $\begin{array}{c}86 \\
(71,1)\end{array}$ & $\begin{array}{c}35 \\
(28,9)\end{array}$ & & $\begin{array}{c}22 \\
(18,2)\end{array}$ & $\begin{array}{c}99 \\
(81,8)\end{array}$ & & $\begin{array}{c}21 \\
(17,4)\end{array}$ & $\begin{array}{c}100 \\
(82,6)\end{array}$ & & $\begin{array}{c}86 \\
(79,6)\end{array}$ & $\begin{array}{c}16 \\
(18,6)\end{array}$ & $\begin{array}{c}70 \\
(81,4)\end{array}$ & & $\begin{array}{c}16 \\
(18,6)\end{array}$ & $\begin{array}{c}70 \\
(81,4)\end{array}$ & \\
\hline Tidak remisi & $5(3,0)$ & $0(0,0)$ & $\begin{array}{c}5 \\
(100,0)\end{array}$ & & $\begin{array}{c}1 \\
(20,0)\end{array}$ & $\begin{array}{c}4 \\
(80,0)\end{array}$ & & $\begin{array}{c}1 \\
(20,0)\end{array}$ & $\begin{array}{c}4 \\
(80,0)\end{array}$ & & $0(0,0)$ & $0(0,0)$ & $0(0,0)$ & & $0(0,0)$ & $0(0,0)$ & \\
\hline Dropped out & $\begin{array}{c}13 \\
(7,8)\end{array}$ & $\begin{array}{c}7 \\
(53,8)\end{array}$ & $\begin{array}{c}6 \\
(46,2)\end{array}$ & & $1(7,7)$ & $\begin{array}{c}12 \\
(92,3)\end{array}$ & & $\begin{array}{c}3 \\
(23,1)\end{array}$ & $\begin{array}{c}10 \\
(76,9)\end{array}$ & & $7(6,5)$ & $0(0,0)$ & $\begin{array}{c}7 \\
(100,0)\end{array}$ & & $\begin{array}{c}2 \\
(28,6)\end{array}$ & $\begin{array}{c}5 \\
(71,4)\end{array}$ & \\
\hline Meninggal & $\begin{array}{c}28 \\
(16,8)\end{array}$ & $\begin{array}{c}15 \\
(53,6)\end{array}$ & $\begin{array}{c}13 \\
(46,4)\end{array}$ & & $\begin{array}{c}5 \\
(17,9)\end{array}$ & $\begin{array}{c}23 \\
(82,1)\end{array}$ & & $\begin{array}{c}6 \\
(21,4)\end{array}$ & $\begin{array}{c}22 \\
(78,6)\end{array}$ & & $\begin{array}{c}15 \\
(13,9)\end{array}$ & $1(6,7)$ & $\begin{array}{c}14 \\
(93,3)\end{array}$ & & $\begin{array}{c}2 \\
(13,3)\end{array}$ & $\begin{array}{c}13 \\
(86,7)\end{array}$ & \\
\hline
\end{tabular}

${ }^{*} \mathrm{P}<0.05$ (analisis statistik menunjukkan signifikansi) 
Eggi Arguni dkk: Petanda imunofenotip CD10 sendiri atau bersama CD3 atau CD13/CD33 sebagai faktor prognosis luaran terapi fase induksi LLA

Tabel 3. Analisis bivariat faktor prognosis terhadap luaran terapi fase induksi (N=154)

\begin{tabular}{|c|c|c|c|c|c|c|c|}
\hline \multirow[t]{2}{*}{ Karakteristik } & \multirow[t]{2}{*}{$\mathrm{N}(\%)$} & \multirow{2}{*}{$\begin{array}{c}\text { Gagal remisi } \\
\text { n (\%) }\end{array}$} & \multirow{2}{*}{$\begin{array}{l}\text { Remisi } \\
\mathrm{n}(\%)\end{array}$} & \multirow[t]{2}{*}{ OR } & \multicolumn{2}{|c|}{$95 \%$ CI } & \multirow[t]{2}{*}{$\mathrm{p}$} \\
\hline & & & & & Lower & Upper & \\
\hline \multicolumn{8}{|l|}{ Jenis kelamin } \\
\hline Laki-laki & $87(56,5)$ & $16(18,4)$ & $71(81,6)$ & 0,725 & 0,396 & 1,326 & 0,295 \\
\hline Perempuan & $67(43,5)$ & $17(25,4)$ & $50(74,6)$ & & & & \\
\hline \multicolumn{8}{|l|}{ Usia } \\
\hline$<1$ th, $\geq 10$ th & $33(21,4)$ & $13(39,4)$ & $20(60,6)$ & 2,383 & 1,331 & 4,268 & $0,005^{*}$ \\
\hline $1-<10$ th & $121(78,6)$ & $20(16,5)$ & $101(83,5)$ & & & & \\
\hline \multicolumn{8}{|l|}{ Angka leukosit } \\
\hline$\geq 50.000 / \mathrm{ml}$ & $51(33,1)$ & $17(33,3)$ & $34(66,7)$ & 2,164 & 1,184 & 3,889 & $0,011^{*}$ \\
\hline$<50.000 / \mathrm{ml}$ & $103(66,9)$ & $16(15,5)$ & $87(84,5)$ & & & & \\
\hline \multicolumn{8}{|l|}{ Kelompok risiko } \\
\hline Tinggi & $87(56,5)$ & $25(28,7)$ & $62(71,3)$ & 2,407 & 1,160 & 4,992 & $0,012^{*}$ \\
\hline Standar & $67(43,5)$ & $8(11,9)$ & $59(88,1)$ & & & & \\
\hline \multicolumn{8}{|l|}{ Imunofenotip } \\
\hline T-ALL & $28(18,2)$ & $11(39,3)$ & $17(60,7)$ & 2,250 & 1,239 & 4,087 & $0,011^{*}$ \\
\hline B-ALL & $126(81,8)$ & $22(17,5)$ & $104(82,5)$ & & & & \\
\hline \multicolumn{8}{|l|}{ Ekspresi CD10 } \\
\hline Negatif & $53(34,4)$ & $18(34,0)$ & $35(66,0)$ & 2,287 & 1,256 & 4,163 & $0,006^{*}$ \\
\hline Positif & $101(65,6)$ & $15(14,9)$ & $86(85,1)$ & & & & \\
\hline \multicolumn{8}{|l|}{ Ekspresi CD3 } \\
\hline Positif & $28(18,2)$ & $6(21,4)$ & $22(78,6)$ & 1,000 & 0,457 & 2,190 & 1,000 \\
\hline Negatif & $126(81,8)$ & $27(21,4)$ & $99(78,6)$ & & & & \\
\hline \multicolumn{8}{|c|}{ Ekspresi CD13/CD33 } \\
\hline Positif & $28(18,2)$ & $7(25,0)$ & $21(75,0)$ & 1,212 & 0,585 & 2,507 & 0,611 \\
\hline Negatif & $126(81,8)$ & $26(20,6)$ & $100(79,4)$ & & & & \\
\hline \multicolumn{8}{|l|}{ Ekspresi CD10(+) } \\
\hline $\mathrm{CD} 3(+)$ & $17(16,8)^{\S}$ & $1(5,9)$ & $16(94,1)$ & 0,353 & 0,050 & 2,507 & 0,254 \\
\hline CD3(-) & $84(83,2)^{\S}$ & $14(16,7)$ & $70(83,3)$ & & & & \\
\hline \multicolumn{8}{|l|}{ Ekspresi CD10(+) } \\
\hline CD13/CD33(+) & $18(17,8)^{\S}$ & $2(11,1)$ & $16(88,9)$ & 0,709 & 0,175 & 2,873 & 0,623 \\
\hline CD13/CD33(-) & $83(82,2)^{\S}$ & $13(15,7)$ & $70(84,3)$ & & & & \\
\hline
\end{tabular}

${ }^{*} \mathrm{P}<0.05$ (analisis statistik menunjukkan signifikansi)

$\S$ Persentase berdasarkan total 101 pasien dengan CD10(+)

CD3 atau CD13/CD33, sebagian besar pasien dengan CD10(+)CD3(+) mengalami remisi ( $\mathrm{n}=16$ dari total 17 pasien dengan $\mathrm{CD} 10(+) \mathrm{CD} 3(+))$. Namun, $81,4 \%$ dari seluruh pasien yang remisi ternyata memiliki ekspresi CD10(+)CD3(-). Penelitian ini juga menunjukkan bahwa sebagian besar pasien dengan CD10(+)CD13/ CD33(+) mengalami remisi $(n=16$ dari total 20 pasien). Namun, sebagian besar pasien yang remisi merupakan CD13/CD33 negatif (81,4\%).

Analisis bivariat dilakukan untuk menguji pengaruh masing-masing faktor risiko terhadap luaran fase induksi (Tabel 3). Analisis bivariat dilakukan pada
154 pasien (pasien dropped out tidak diperhitungkan). Analisis multivariat kemudian dilakukan untuk menentukan faktor prognosis yang independen terhadap luaran terapi induksi. Hasil analisis multivariat stepwise (Tabel 4) menunjukkan bahwa kelompok usia $<1$ tahun dan $\geq 10$ tahun memiliki risiko 3,1 kali lebih tinggi terjadi gagal remisi dibandingkan dengan pasien LLA anak yang terdiagnosis pada usia 1 tahun sampai $<10$ tahun (IK95\% 1,271-7,625; p=0,013). Pasien dengan ekspresi CD10 negatif juga akan meningkatkan risiko gagal remisi 2,7 kali dibanding dengan ekspresi CD10 positif (IK95\% 1,171-6,232; p=0,020). 
Eggi Arguni dkk: Petanda imunofenotip CD10 sendiri atau bersama CD3 atau CD13/CD33 sebagai faktor prognosis luaran terapi fase induksi LLA

Tabel 4. Analisis multivariat faktor prognosis terhadap luaran terapi

\begin{tabular}{lcccc}
\hline Karakteristik & OR & p & IK95\% & Uower \\
\cline { 4 - 5 } Faktor prognosis gagal remisi fase induksi & & & & 7,625 \\
Usia $<1$ tahun dan $\geq 10$ tahun & 3,114 & 0,013 & 1,271 & 6,232 \\
Ekspresi CD10 negatif & 2,702 & 0,020 & 1,171 &
\end{tabular}

\section{Pembahasan}

Penelitian ini serupa dengan penelitian lain yang melaporkan bahwa B-ALL berkisar lebih dari $80 \%$ dari jumlah LLA yang terdiagnosis, dan jumlah T-ALL berkisar 18,6\%. Ekspresi CD10 ditemukan pada 95,63\% kasus B-ALL anak dan 18,1\% pada kasus T-ALL. ${ }^{10}$ Sementara penelitian lain menunjukkan ekspresi CD10 positif pada 91,2\% kasus B-ALL dan pada $21,2 \%$ pada kasus T-ALL. ${ }^{11}$

T-lineage ALL ditentukan berdasarkan ekspresi marker CD2, CD7, CD1a, CD3 dan CD5. ${ }^{12}$ Terdapat heterogenitas dalam ekspresi imunofenotip seiring dengan maturasi sel T limfosit. ${ }^{13}$ Pada CD3, sebelum terbentuk sCD3 (surface CD3) maka akan terbentuk cyCD3 (cytoplasmic CD3) sehingga berdasarkan maturasi maka T-lineage ALL dikelompokkan menjadi pre-T, Thymic dan non-T. Prognosis T-lineage ALL tidak sebaik B-ALL, sekitar 30\% pasien T-ALL akan relaps pada pengobatan kemoterapi awal. ${ }^{7}$

Myeloid associated antigens CD13 dan CD33 merupakan antigen yang umum diekspresikan oleh LLA anak sehingga representatif digunakan untuk menentukan myeloid associated ALL pada anak. ${ }^{12}$ Sekitar 5\%-20\% dari seluruh kasus LLA mengekspresikan dua atau lebih petanda myeloid. ${ }^{11,14,15}$

Ekspresi CD10 dihubungkan dengan prognosis yang lebih baik pada pasien LLA anak pada penelitian terdahulu. ${ }^{16-18}$ Dalam telaah Pui $\mathrm{dkk}^{18}$ menyatakan bahwa ekspresi CD10 berhubungan dengan beberapa gambaran klinis yang baik pada anak dengan B-ALL, tetapi bukan merupakan faktor prognostik yang independen, baik pada B-ALL maupun T-ALL. Consolini $\mathrm{dkk}^{10}$ menyatakan bahwa ekspresi CD10 juga tidak menjadi faktor prognostik independen yang bermakna pada B-ALL dan T-ALL. Pada penelitian kami, ekspresi CD10 berhubungan dengan luaran terapi fase induksi.

CD10 negatif banyak dihubungkan dengan event free survival (EFS) yang rendah karena berhubungan dengan populasi yang banyak ditemukan pada 55\% leukemia bayi (infant acute leukemia). ${ }^{9}$ Prognosis yang buruk ini mungkin disebabkan karena hampir 85\% kejadian kelainan genetik, seperti MLL gene rearrangement pada kromosom $11 \mathrm{q} 23$, terjadi pada bayi usia kurang dari 12 bulan. ${ }^{19}$ Semakin muda usia, semakin tinggi frekuensi translokasi MLL. ${ }^{19,20}$ Prognosis dari kelompok infant leukemia dengan translokasi ini sangat buruk (5-year EFS 40-50\%). ${ }^{21,22}$ Frekuensi IgH dan $\mathrm{V} \beta$ rearrangement relatif sering terjadi pada CD10 negatif infant leukemia yang menunjukkan bahwa deferensiasi sel mengalami gangguan sehingga tidak bisa berdiferensiasi ke tahap (stage) sel berikutnya. ${ }^{23}$ Sel-sel leukemia dengan CD10 positif memiliki kadar $c$-myc yang tinggi sehingga tingkat apoptosisnya pun tinggi dibandingkan dengan sel-sel dengan CD10 negatif. Sel dengan CD10 negatif memiliki kapasiats cell-cycling dan ekspresi c-myc yang rendah. ${ }^{24}$ Mekanisme cell-cycling dan apoptosis yang rendah ini menyebabkan sel-sel leukemia tidak susceptible terhadap external signal, termasuk terhadap obat kemoterapi.

Secara umum, T-ALL mempunyai prognosis yang lebih buruk dibandingkan dengan B-ALL karena sering dihubungkan dengan jenis kelamin laki-laki, usia anak yang lebih tua, jumlah angka lekosit yang tinggi, adanya mediastinal mass dan leukemia sistem susunan saraf pusat. ${ }^{17}$ Imunofenotip CD3 berhubungan dengan EFS yang lebih rendah dan dikelompokkan pada kelompok pasien yang membutuhkan protokol tersendiri diperkirakan berdasar pada sifat farmakologis dari sel blast $T$ yang relatif lebih sensitif terhadap asparaginase dan relatif tidak sensitif terhadap dosis rendah methotrexate. ${ }^{25}$ Dalam satu penelitian terbaru ditunjukkan regimen terapi yang lebih intensif, outcome pasien T-ALL memberikan hasil yang serupa dengan pasien B-ALL. ${ }^{26}$

Signifikansi klinis dari ekspresi myeloid antigen pada LLA anak masih kontroversial. Penelitian oleh Wiersma dkk. ${ }^{27}$ melaporkan bahwa myeloid antigen 
Eggi Arguni dkk: Petanda imunofenotip CD10 sendiri atau bersama CD3 atau CD13/CD33 sebagai faktor prognosis luaran terapi fase induksi LLA

merupakan faktor prognosis buruk bagi luaran EFS. Bukti tersebut sejalan dengan observasi pre-klinik yang menunjukkan bahwa sel-sel yang berasal dari pasien LLA dengan myeloid antigen positif lebih resisten terhadap glucocorticoid-induced killing dibanding dengan myeloid antigen negatif. ${ }^{28}$ Antigen myeloid yang terekspresi dalam sel leukemia (LLA) diduga disebabkan adanya abnormalitas ekspresi gen, transformasi neoplasma dari progenitor sel lymphoidl myeloid atau transformasi sel prekursor multipoten lymphohematopoietic. Abnormalitas inilah yang dispekulasikan sebagai faktor prognosis yang buruk bagi luaran terapi pasien LLA anak dengan myeloid antigen positif. Pada kasus LLA yang tidak respon terapi, adanya ekspresi antigen myeloid tetap harus dipertimbangkan sebagai suatu faktor prognosis karena dapat terjadi gangguan biologis dan kemungkinan akan memiliki prognosis yang berbeda. ${ }^{20}$

Relaps setelah remisi pada akhir kemoterapi fase induksi masih merupakan hambatan yang besar dalam mencapai survive, dan menjadi faktor yang bertanggung jawab terhadap kematian pada hampir $20 \%$ kasus LLA anak. ${ }^{29}$ Mekanisme relaps pada LLA memiliki dua hipotesis. Hipotesis pertama menyebutkan bahwa relaps dapat timbul dari induksi resistensi sel leukemia selama kemoterapi, mungkin disebabkan via mutasi genetik. Hipotesis kedua menyebutkan bahwa relaps dapat terjadi melalui peristiwa seleksi dan ekspansi subpopulasi sel yang sebenarnya sudah resisten terhadap kemoterapi. ${ }^{30,31}$ Bila subpopulasi sel leukemia yang resisten kemoterapi ini dapat terdeteksi sejak diagnosis ditegakkan maka hal ini dapat digunakan sebagai faktor prediktor bagi timbulnya relaps di kemudian hari.

Gambaran klinis, pemeriksaan laboratorium, pemeriksaan imunofenotiping dan molekuler harus selalu menjadi pertimbangan bersama dalam stratifikasi awal sehingga kelompok yang benar risiko tinggi dapat diterapi progresif dan kelompok yang benar risiko rendah dapat menggunakan terapi minimal untuk menghindari toksisitas obat yang tinggi. Rekomendasi ini diperlukan untuk meningkatkan usia harapan hidup anak dengan LLA.

\section{Kesimpulan}

Kami menyimpulkan bahwa ketiadaan ekspresi CD10 merupakan faktor prognosis independen terhadap kejadian gagal remisi pada akhir fase induksi. Ekspresi imunofenotip CD10 bersama CD3 dan CD13/CD33, bukan merupakan faktor prognosis bagi luaran terapi fase induksi.

\section{Daftar pustaka}

1. Friedmann AM, Weinstein HJ. 2000. The role of prognostic feature in treatment of childhood acute lymphoblastic leukemia. Oncologist 2000;3:321-8.

2. Hastings C. The Children's Hospital Oakland Hematology/ Oncology Handbook. St.Louis: Mosby;2002.h.153-9.

3. Margolin JF, Steuber CP, Poplack DG. Acute lymphoblastic leukemia. Dalam: Pizzo PA, Poplack DG, editor. Principles and practice of pediatric oncology. Lippincott Williams \& Wilkins, Philadelphia;2002.h.489-544.

4. Sutaryo, Sumadiono, Suhadi. The pilot protocol of Wijaya Kusuma acute lymphoblastic leukemia of childhood 1999. Indonesian Multicentre Study. Yogyakarta, Indonesia: Gadjah Mada University Press; 1999.

5. Schrappe M, Reiter A, Ludwig WD, Harbott J, Zimmermann M, Hiddmann W, dkk. Improved outcome in childhood acute lymphoblastic leukemia despite reduced use of anthracyclines and cranial radiotherapy: results of trial ALL-BFM 90. German-Austrian-Swiss ALL-BFM Study Group. Blood 2000;95:3310-22.

6. Silverman LB, Gelber RD, Dalton VK, Asselin BL, Barr RD, Clavell LA, dkk. Improved outcome for children with acute lymphoblastic leukemia: results of Dana-Farber Consortium Protocol 91-01. Blood 2001;97:1211-8.

7. Pui CH, Evans WE. Treatment of acute lymphoblastic leukemia. N Engl J Med 2006;354:166-78.

8. Mulatsih S, Sumadiono, Sutaryo, Purwanto. The result of treating children's acute lymphoblastic leukemia (ALL) in Dr. Sardjito Hospital with WK-ALL Protocol 1999-2002. Bulletin Ilmu Kesehatan Anak tahun XXXI 2005;17:808-19.

9. Béné MC, Faure GC. CD10 in acute leukemias. GEIL (Groupe d'Etude Immunologique des Leucémies). Haematologica 1997;82:205-10.

10. Consolini R, Legitimo A, Rondelli R, Guguelmi C, Barisone E, Lippi A, dkk. Clinical relevance of CD10 expression in childhood ALL. The Italian Association for Pediatric Hematology and Oncology. Haematologica 1998;83:967-73.

11. Bachir F, Bennani S, Lahjouji A, Cherkaoui S, Harif M, Khattab M, dkk. Characterization of acute lymphoblastic leukemia subtypes in Moroccan children. Int J Pediatr 2009; doi: 10.1155/2009/674801.

12. Putti MC, Rondelli R, Cocito MG, Aricò M, Sainati L, Conter 
Eggi Arguni dkk: Petanda imunofenotip CD10 sendiri atau bersama CD3 atau CD13/CD33 sebagai faktor prognosis luaran terapi fase induksi LLA

V, dkk. Expression of myeloid markers lacks prognostic impact in children treated for acute lymphoblastic leukemia. Italian experience in AIEOP ALL 88-91 studies. Blood 1998;92:1-9.

13. Gómez E, San Miguel JF, González M, Orfao A, López-Berges C, Ríos A, Lopez dkk. Heterogeneity of T cell lymphoblastic leukaemias. J Clin Pathol 1991;44:628-31.

14. Pui CH, Raimondi SC, Head DR, Schell MJ, Rivera GK, Mirro J Jr, dkk. Characterization of childhood acute leukemia with multiple myeloid and lymphoid markers at diagnosis and at relapse. Blood 1991;78:1327-37.

15. Uckun FM, Sather HN, Gaynon PS, Arthur DC, Trigg ME, Tubergen DG, dkk. Clinical features and treatment outcome of children with myeloid antigen positive acute lymphoblastic leukemia: a report from the Children's Cancer Group. Blood 1997;90:28-35.

16. Sallan SE, Ritz J, Pesando J, Gelber R, O’Brien C, Hitchcock $S$, dkk. Cell surface antigens: prognostic implications in childhood acute lymphoblastic leukemia. Blood 1980; 55:395402.

17. Pui CH, Behm FG, Singh B, Rivera GK, Schell MJ, Roberts WM, dkk. Myeloid-associated antigen expression lacks prognostic value in childhood acute lymphoblastic leukemia treated with intensive multiagent chemotherapy. Blood 1990;75:198-202.

18. Pui CH, Behm FG, Crist WM. Clinical and biologic relevance of immunologic marker studies in childhood acute lymphoblastic leukemia. Blood 1993;82:343-62.

19. Emerenciano M, Koifman S, Pombo-de-Oliveira MS. Acute leukemia in early childhood. Braz J Med Biol Res 2007;40:749-60.

20. Greaves MF, Chan LC, Furley AJW, Watt SM, Molgaard HV. Lineage promiscuity in hemopoietic differentiation and leukemia. Blood 1986;67:1-11.

21. Pui CH, Kane JR, Crist WM. Biology and treatment of infant leukemias. Leukemia 1995;9:762-9.
22. Stam RW, den Boer ML, Pieters R. Towards targeted therapy for infant acute lymphoblastic leukaemia. Br J Haematol 2006;132:539-51.

23. Katz F, Malcolm S, Gibbons B, Tilly R, Lam G, Robertson ME, dkk. Cellular and molecular studies on infant null acute lymphoblastic leukemia. Blood 1988;71:1438-47.

24. Cutrona G, Tasso P, Dono M, Roncella S, Ulivi M, Carpaneto EM, dkk. CD10 is a marker for cycling cells with propensity to apoptosis in childhood ALL. Br J Cancer 2002;86:1776-85.

25. Carrol WL, Bhojwani D, Min DJ, Raetz E, Relling M, Davies S, dkk. Pediatric acute lymphoblastic leukemia. Hematology Am Soc Hematol Educ Program 2003;102-31.

26. Goldberg JM, Silverman LB, Levy DE, Dalto VK, Gelber RD, Lehmann L, dkk. Childhood T-cell acute lymphoblastic leukemia: the Dana-Farber Cancer Institute acute lymphoblastic leukemia consortium experience. J Clin Oncol 2003;21:3616-22.

27. Wiersma SR, Ortega J, Sobel E, Weinberg KL. Clinical importance of myeloid-antigen expression in acute lymphoblastic leukemia of childhood. N Engl J Med 1991;324:800-8.

28. Kaspers GJ, Kardos G, Pieters R, Van Zantwijk CH, Klumper E, Hählen K, dkk. Different cellular drug resistance profiles in childhood lymphoblastic and non-lymphoblastic leukemia: a preliminary report. Leukemia 1994;8:1224-9.

29. Pui CH, Sandlund JT, Pei D, Campana D, Rivera GK, Ribeiro RC, dkk. Improved outcome for children with acute lymphoblastic leukemia: results of Total Therapy Study XIIIB at St. Jude Children's Research Hospital. Blood 2004;104:2690-6.

30. Choi S, Henderson MJ, Kwan E, Beesley AH, Sutton R, Bahar AY, dkk. Relapse in children with acute lymphoblastic leukemia involving selection of a preexisting drug-resistant subclone. Blood 2007;110:632-9.

31. Henderson MJ, Choi S, Beesley AH, Sutton R, Venn NC, Marshall GM, dkk. Mechanism of relapse in pediatric acute lymphoblastic leukemia. Cell cycle 2008;7:1315-20. 